\title{
Operative invasiveness does not affect the prognosis of patients with non-small cell lung cancer
}

\author{
Nozomu Motono* ${ }^{*}$, Shun Iwai, Yoshihito lijima, Katsuo Usuda and Hidetaka Uramoto
}

\begin{abstract}
Background: The relationship between operative invasiveness and the prognosis in non-small cell lung cancer (NSCLC) patients who have undergone surgery has been controversial.

Methods: Clinical data were analyzed for 463 NSCLC patients. Operative invasiveness was defined by wound length, operation time, and the postoperative C-reactive protein (postCRP) level. The operative approach was divided into video-assisted thoracic surgery (VATS) and thoracotomy.

Results: The wound length and operation time were significantly correlated with the postCRP level (correlation coefficient $(C C)=0.39, p<0.01 ; C C=0.54, p<0.01$, respectively). The postCRP level in the VATS group was significantly lower than that in the thoracotomy group $(12.2 \mathrm{mg} / \mathrm{dl}$ vs $20.58 \mathrm{mg} / \mathrm{dl}, p<0.01)$. The relapse-free survival differed significantly based on wound length $(p<0.01)$, operation time $(p=0.01)$, CRP level $(p<0.01)$, and operative approach $(p<0.01)$. The carcinoembryonic antigen level (hazard ratio [HR], $1.58 ; p=0.02)$, pathological stage (pStage) (HR, 2.57; $p<0.01)$, vascular invasion (HR, 1.95; $p=0.01)$, and preoperative CRP level (preCRP) (HR, 1.91; $p<0.01$ ) were identified as significant prognostic factors for relapse-free survival in a multivariate analysis. Furthermore, the multivariate analysis showed that smoking history $(\mathrm{HR}, 2.36 ; p=0.03)$, pStage $(H \mathrm{R}, 3.26 ; p<0.01)$, and preCRP level were significant prognostic factors for overall survival.
\end{abstract}

Conclusion: Preoperative CRP level was associated with poor prognosis. Although the VATS approach might be less invasive procedure for NSCLC patients, operative invasiveness does not affect the prognosis.

Keywords: Operative invasiveness, Video-assisted thoracic surgery, Non-small cell lung cancer

\section{Background}

Video-assisted thoracic surgery (VATS) for patients with non-small cell lung cancer (NSCLC) has been widely adopted and the advantages of the VATS approach have been reported [1-7]. These reports have shown that VATS is associated with less pain, a shorter hospital stay, less reduction of the inflammatory-immune response, and the maintenance of the postoperative respiratory function in comparison to thoracotomy.

\footnotetext{
* Correspondence: motono@kanazawa-med.ac.jp

Department of Thoracic Surgery, Kanazawa Medical University, 1-1 Daigaku, Uchinada, Ishikawa 920-0293, Japan
}

Furthermore, it was reported that VATS is associated with significantly less response in C-reactive protein (CRP) and cytokine levels. Acute-phase proteins (APPs) are a series of proteins that are sensitive to inflammation and body stress including infection, surgical trauma, certain diseases and tissue damage $[8,9]$. The concentrations of certain APPs, including CRP may increase markedly during stress or under pathological conditions. Levels of the CRP increase as a result of the inflammatory response to infection or tissue damage, and have been used to evaluate surgery technique, infection and pathology progress. The serum concentration of CRP

(c) The Author(s). 2020 Open Access This article is licensed under a Creative Commons Attribution 4.0 International License, which permits use, sharing, adaptation, distribution and reproduction in any medium or format, as long as you give appropriate credit to the original author(s) and the source, provide a link to the Creative Commons licence, and indicate if changes were made. The images or other third party material in this article are included in the article's Creative Commons licence, unless indicated otherwise in a credit line to the material. If material is not included in the article's Creative Commons licence and your intended use is not permitted by statutory regulation or exceeds the permitted use, you will need to obtain permission directly from the copyright holder. To view a copy of this licence, visit http://creativecommons.org/licenses/by/4.0/ The Creative Commons Public Domain Dedication waiver (http://creativecommons.org/publicdomain/zero/1.0/) applies to the data made available in this article, unless otherwise stated in a credit line to the data. 
was significantly higher in the open group, compared with the VATS group. Thus, the VATS approach has been considered to be less invasive [9]. However, the prognostic impact of the operative invasiveness-including the postoperative inflammatory response-in NSCL $\mathrm{C}$ patients is uncertain.

In the present study, we evaluated the prognostic impact of the operative invasiveness after surgery in NCSL C patients.

\section{Methods}

\section{Patients}

One thousand one hundred fifty-six NSCLC patients who underwent complete resection in Kanazawa Medical University between January 2002 and December 2018 were identified. Among these, 463 NSCLC patients had available data. These patients were enrolled in the present retrospective study.

Regarding the data collected, the clinical factors included the sex, age, smoking history, comorbidities, and the carcinoembryonic antigen (CEA) and preoperative CRP (preCRP) levels. The smoking history was assessed using the Brinkman index, which is calculated as the numbers of cigarettes smoked per day multiplied by the number of years for which the subject has smoked. Comorbidities were evaluated by the Charlson Comorbidity Index [11]. The perioperative factors included the wound length, operative approach, operative procedure, operation time, postoperative CRP (postCRP) level, and postoperative complications. The operative approach was divided into three categories: complete VATS (CVATS; surgery was only performed to provide a monitoring view); hybrid VATS (H-VATS; surgery was combined with direct vision without rib spreading); and thoracotomy. Postoperative complications were categorized into five grades according to the Clavien-Dindo classification system [12]. Histological type, differentiation, lymphatic invasion (Ly), vascular invasion (V), and pathological stage (pStage) were evaluated as pathological factors.

\section{Statistical analyses}

The correlation coefficient was evaluated by Spearman's rank correlation coefficient. The cut-off values of factors associated with recurrence were calculated by an ROC curve analysis and prognostic analyses were performed based on these cutoff values. The cumulative survival rates were calculated by the Kaplan-Meier method, and survival curves were compared using a log-rank test. Univariate and multivariate analyses using a Cox proportional hazards model were conducted to determine the risk factors for relapse-free survival (RFS) and overall survival (OS). All statistical analyses were two-sided, and $p$ values of $<0.05$ were considered to indicate statistical significance. The statistical analyses were conducted using the JMP software program (Version 13.2; SAS Institute Inc., Cary, NC, USA).

\section{Results}

\section{Patient characteristics}

The clinicopathological characteristics of the 463 patients who were included in the present study are listed in Table 1 . Two hundred eighty-one patients (61\%) were men, and the median age was 68 years. The median Brinkman index was 600, the median CEA level was 3.6 $\mathrm{ng} / \mathrm{ml}$, and the median preCRP level was $0.1 \mathrm{ng} / \mathrm{ml}$. More than half of patients had a low comorbidity index (Charlson Comorbidity Index of $0, n=282 ; 61 \%$ ).

\section{Perioperative factors}

The operative approach was C-VATS in 77 patients (17\%), H-VATS in 321 (69\%), and thoracotomy in 65 (14\%). The median wound length was $8 \mathrm{~cm}$, and the median operation time was $230 \mathrm{~min}$. Sublobar resection was performed in 26 patients $(6 \%)$, and lobectomy or more was performed in 437 patients (94\%). The patients' postoperative complications were classified as ClavienDindo grade 0 in 340 patients(73.4\%), grade $\mathrm{I}$ in 20 (4.3\%), grade II in 45 (9.7\%), grade IIIa in 53 (11.4\%), and grade IIIb in $5(1.2 \%)$. The median postCRP was $13.39 \mathrm{ng} / \mathrm{ml}$. The perioperative factors of the VATS and thoracotomy groups are shown in Table 2. VATS was associated with a significantly shorter wound length $(p<0.01)$ and operation time $(\mathrm{p}<0.01)$, and lower postCRP level $(\mathrm{p}<0.01)$ in comparison to thoracotomy.

\section{Pathological factors}

The pStage was IA in 225 patients (48.5\%), IB in 101 (21.8\%), IIA in $48(10.4 \%)$, IIB in $43(9.3 \%)$, and IIIA in $46(10 \%)$. Adenocarcinoma was diagnosed in 350 patients (76\%), squamous cell carcinoma was diagnosed in 91 patients (19.6\%), and other types of lung cancer (adenosquamous cell carcinoma, pleomorphic carcinoma, large cell neuroendocrine carcinoma, and large cell carcinoma) were diagnosed in 22 patients (4.4\%). The grade of differentiation was grade 1 (G1) in 173 patients (37.4\%), grade 2 (G2) in $203(43.8 \%)$, grade 3 (G3) in 75 (16.2\%), and grade 4 (G4) in $1282.6 \%$ ). Ly was present in 192 patients $(41.5 \%)$, and $\mathrm{V}$ was present in 225 patients $(49 \%)$.

\section{Correlation coefficients}

The correlation coefficients are shown in Table 3. Positive correlations were observed between wound length and postCRP level (correlation coefficient; $r=0.39$, $p<0.01$ ), between wound length and operation time $(\mathrm{r}=0.43, \mathrm{p}<0.01)$, and between operation time and postCRP level $(r=0.54, p<0.03)$. 
Table 1 Patient characteristics

\begin{tabular}{ll}
\hline Gender (male / female) & $281(61 \%) / 182(39 \%)$ \\
Age (y.o.), median (range) & $68.4(34-87)$ \\
Smoking index, median (range) & $600(0-3600)$ \\
CEA (ng/ml), median (range) & $3.6(0.5-236)$ \\
Charlson comorbidity index (0 / 1 / 2 / 3 / 4) & $282(61 \%) / 108(23.2 \%) / 62(13.4 \%) / 9(2 \%) / 2(0.4 \%)$ \\
Wound length (cm), median (range) & $8(3-25)$ \\
Approach (C-VATS / Hybrid / Thoracotomy) & $77(17 \%) / 321(69 \%) / 65(14 \%)$ \\
Operative procedure (Seg / Lob / Bilob / Pneumo) & $26(6 \%) / 409(88 \%) / 10(2 \%) / 18(4 \%)$ \\
Operation time (min), median (range) & $230(67-674)$ \\
Histology (Ad / Sq / AdSq / LCNEC / Large / Pleo) & $350(76 \%) / 91(19.6 \%) / 8(1.6 \%) / 9(1.8 \%) / 3(0.6 \%) / 2(0.4 \%)$ \\
Differentiation (G1 / 2 / 3 / 4) & $173(37.4 \%) / 203(43.8 \%) / 75(16.2 \%) / 12(2.6 \%)$ \\
Ly (0 / 1) & $271(58.5 \%) / 192(41.5 \%)$ \\
V (0 / 1) & $236(51 \%) / 225(49 \%)$ \\
pStage (IA / IB / IIA / IIB / IIA) & $225(48.5 \%) / 101(21.8 \%) / 48(10.4 \%) / 43(9.3 \%) / 46(10 \%)$ \\
Preoperative CRP (ng/ml), median (range) & $0.1(0.02-14.89)$ \\
Postoperative CRP (ng/ml), median (range) & $13.39(0.66-36.28)$ \\
Clavien-Dindo grade (0 / 1 / 2 / 3a / 3b) & $340(73.4 \%) / 20(4.3 \%) / 45$ (9.7\%) / 53 (11.4\%) / 5 (1.2\%) \\
\hline
\end{tabular}

CEA carcinoembryonic antigen, VATS video-assisted thoracic surgery, Seg segmentectomy, Lob lobectomy, Bilob bilobectomy, Pneumo pneumonectomy, Ad adenocarcinoma, Sq squamous cell carcinoma, AdSq adenosquamous cell carcinoma, LCNEC large cell neuroendocrine cell carcinoma, Large large cell carcinoma, Pleo pleomorphic cell carcinoma, $G$ grade, Ly lymphatic invasion, $V$ vascular invasion; $p$ Stage pathological stage, CRP C-reactive protein

\section{Cutoff values calculated from ROC curves}

The cutoff values of factors associated with recurrence were calculated by an ROC curve analysis. The following cutoff values were determined: operation time, $248 \mathrm{~min}$; wound length, $10 \mathrm{~cm}$; preCRP level, $0.14 \mathrm{ng} / \mathrm{ml}$; and postCRP level, $14.49 \mathrm{ng} / \mathrm{ml}$.

\section{Survival analyses}

RFS is shown in Fig. 1. There were significant prognostic differences according to the operative approach $(p<0.01)$, wound length $(\mathrm{p}<0.01)$, operation time $(p=0.01)$, preCRP level $(p<0.01)$, and postCRP level $(\mathrm{p}<0.01)$. OS is shown in Fig. 2. There were significant prognostic differences according to the operative approach $(p<0.01)$, wound length $(p<0.01)$, operation time $(p=0.02)$, preCRP level $(p<0.01)$, and postCRP level $(p<0.01)$.

\section{Univariate and multivariate analyses}

The univariate and multivariate analyses of factors associated with RFS are summarized in Table 4. Sex (hazard

Table 2 The differences of perioperative factors by operative approach

\begin{tabular}{llll}
\hline Variables & VATS & Thoracotomy & $P$ value \\
\hline Wound length & $7(3-18)$ & $20(8-25)$ & $<0.01$ \\
Operation time & $203(67-674)$ & $320(154-672)$ & $<0.01$ \\
Postoperative CRP & $12.2(0.66-36.28)$ & $20.58(6.4-33.72)$ & $<0.01$ \\
\hline
\end{tabular}

VATS video-assisted thoracic surgery, CRP C-reactive protein ratio $[\mathrm{HR}], 1.92 ; p<0.01)$, smoking history (HR, 2.10; $p<0.01$ ), CEA (HR, 1.98; $\mathrm{p}<0.01$ ), operative approach (HR, 0.58; $<<0.01$ ), wound length (HR, 2.07; $\mathrm{p}<0.01$ ), operation time $(\mathrm{HR}, 1.62 ; p=0.01)$, operative procedure (HR, 1.99; $p=0.04)$, differentiation (HR, 2.09; $p<0.01$ ), Ly (HR, 2.89; p < 0.01), V (HR, 3.26; p < 0.01), pStage (HR, 4.59; $<<0.01$ ), preCRP level (HR, 2.80; $<<0.01$ ), and postCRP level (HR, $1.89 ; p<0.01)$ were identified as significant prognostic factors in the univariate analysis. CEA (HR, 1.58; $p=0.02), \mathrm{V}(\mathrm{HR}, 1.95 ; \mathrm{p}=0.01)$, pStage (HR, 2.57; $p<0.01$ ), and preCRP level (HR, 1.91; $\mathrm{p}<0.01$ ) were identified as significant prognostic factors in the multivariate analysis.

The results of the univariate and multivariate analyses of factors associated with OS are summarized in Table 5. Sex (HR, 3.32; $p<0.01)$, smoking history (HR, 4.12; $<<0.01)$, CEA (HR, 1.88; $<<0.01$ ), operative approach (HR, $0.45 ; p<0.01)$, wound length (HR, $2.41 p<0.01$ ), operation time (HR, 1.84 $p=$ $0.02)$, operative procedure $(H R, 2.98 ; p<0.01)$, differentiation (HR, 1.92; $\mathrm{p}<0.01)$, Ly (HR, $1.95 \mathrm{p}<0.01)$, $\mathrm{V}(\mathrm{HR}, 3.36 ; \mathrm{p}<0.01)$, pStage (HR, 4.83; $\mathrm{p}<0.01)$,

Table 3 Correlation coefficient

\begin{tabular}{lll}
\hline Variable & Correlation coefficient & $P$ value \\
\hline Wound length vs Postoperative CRP & 0.399 & $<0.01$ \\
Operation time vs Postoperative CRP & 0.544 & $<0.01$ \\
Operation time vs Wound length & 0.432 & $<0.01$ \\
\hline
\end{tabular}

CRP C-reactive protein 


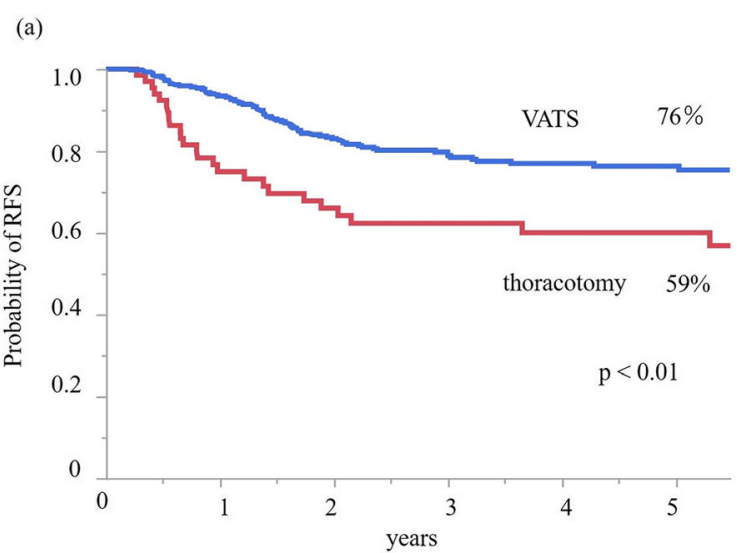

(c)

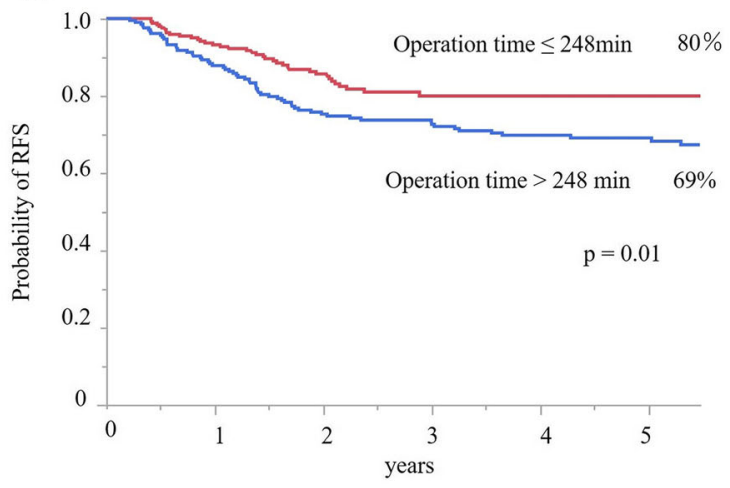

(e)

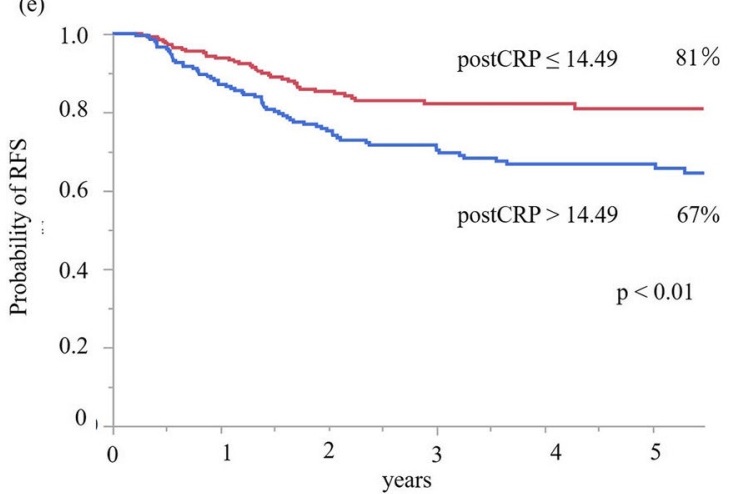

(b)

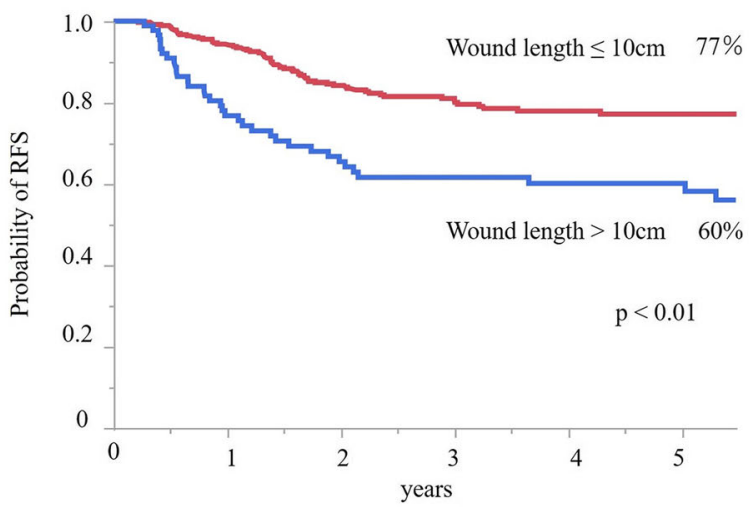

(d)

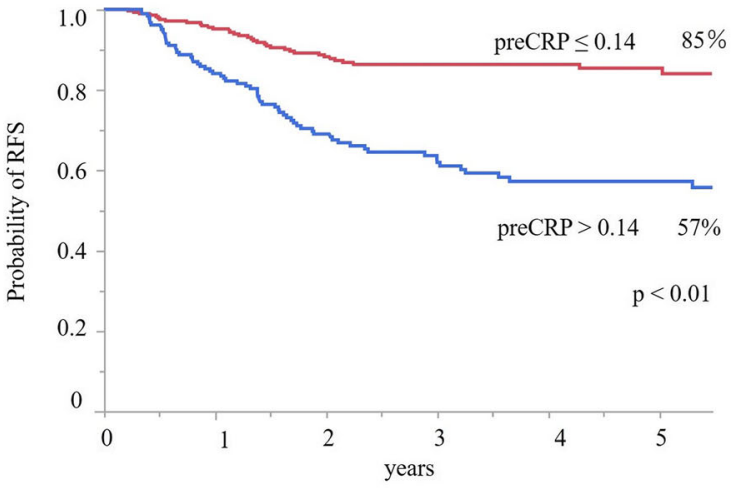

Fig. 1 a Relapse-free survival rate in the VATS group was significantly longer than in the thoracotomy group. b Relapse-free survival in patients with a wound length of $\leq 10 \mathrm{~cm}$ was significantly longer than that in patients with a wound length of $>10 \mathrm{~cm}$. $\mathbf{c}$ Relapse-free survival in patients with an operation time of $\leq 248$ min was significantly longer than that in patients with an operation time of $>248$ min. $\mathbf{d}$ Relapse-free survival in patients with a preCRP level of $\leq 0.14$ was significantly longer than that in patients with a preCRP level of $>0.14$. e Relapse-free survival in patients with a postCRP level of $\leq 14.49$ was significantly longer than that in patients with a postCRP level of $>14.49$

preCRP level (HR, 2.85; $p<0.01)$, and postCRP level (HR, 2.20; $p<0.01)$ were identified as significant prognostic factors in the univariate analysis. Smoking history (HR, 2.36; $p=0.03)$, V (HR, 2.80; $p<0.01)$, and pStage $(\mathrm{HR}, 3.26 ; p<0.01)$ were identified as significant prognostic factors in the multivariate analysis.

\section{Sub-analyses}

The univariate and multivariate analyses of factors associated with RFS for pathological stage I are summarized in Table 6 (Supplemental 1). Sex (HR, 2.49; $p<0.01$ ), smoking history (HR, 3.19; $\mathrm{p}<0.01)$, CEA (HR, 2.08; $p=0.01)$, histology (HR, 2.01; $p=0.03)$, differentiation 

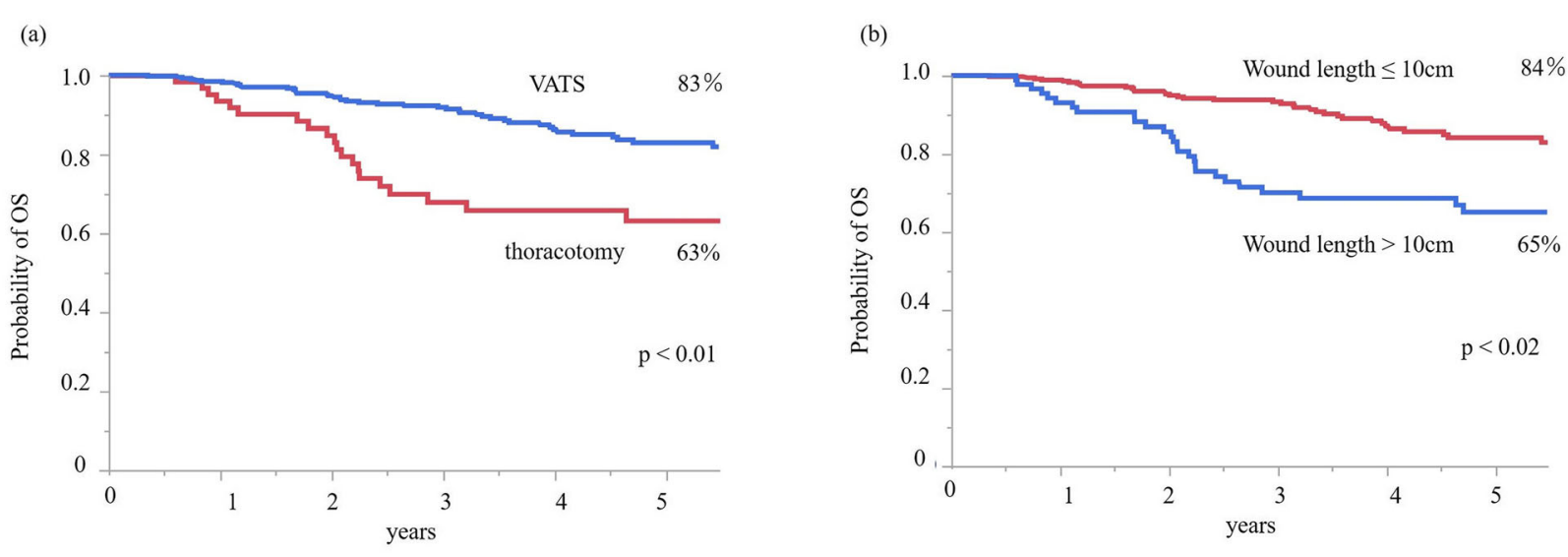

(c)
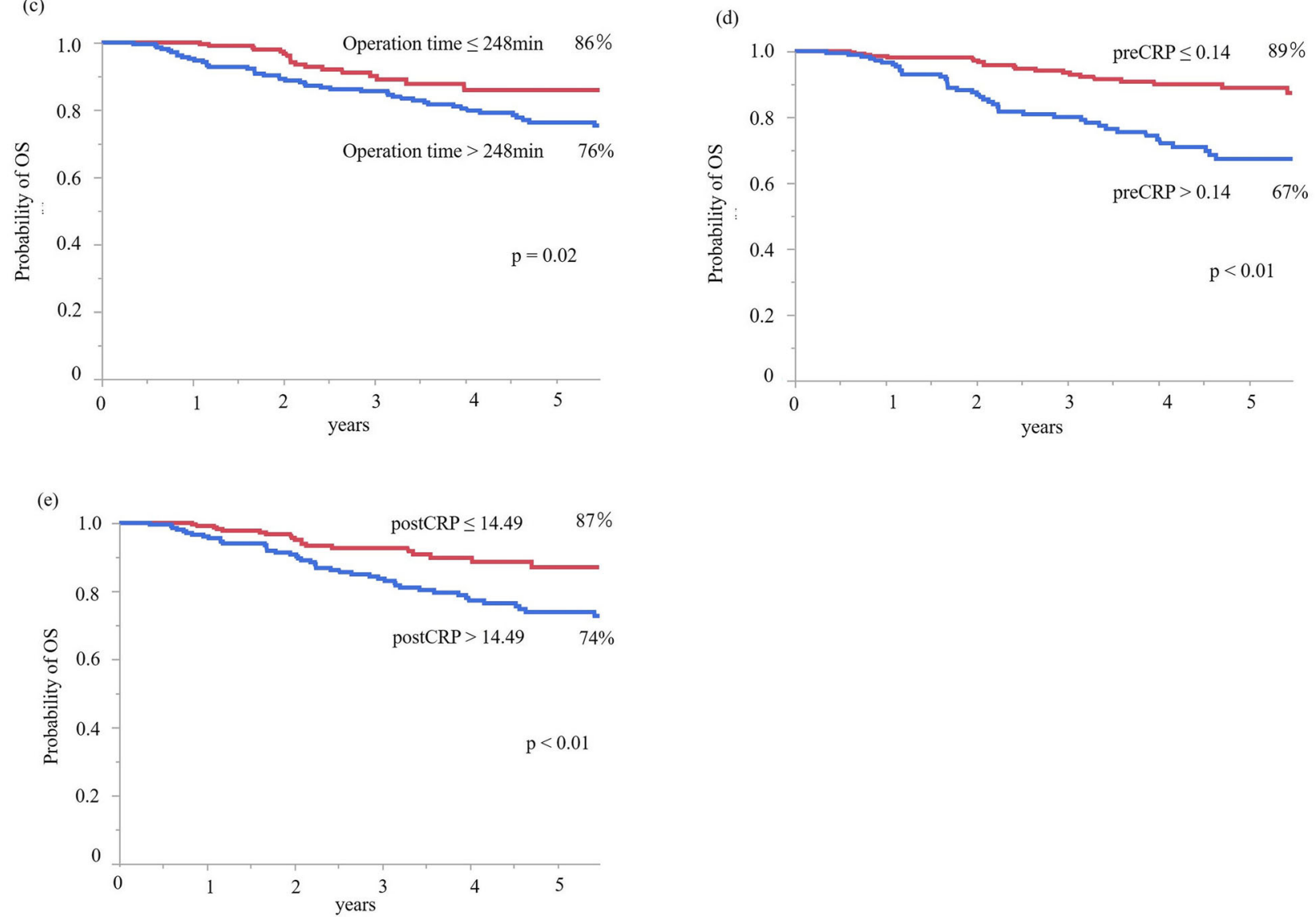

Fig. 2 a Overall survival rate in the VATS group was significantly longer in comparison to the thoracotomy group. b Overall survival in the wound length $\leq 10 \mathrm{~cm}$ group was significantly longer than that in the wound length $>10 \mathrm{~cm}$. c Overall survival in the operation time $\leq 248$ min group was significantly longer than that in the operation time $>248$ min group. $\mathbf{d}$ Overall survival in the preCRP $\leq 0.14$ group was significantly longer than that in the preCRP $>0.14$ group. e Overall survival in the postCRP $\leq 14.49$ group was significantly longer than that in the postCRP $>14.49$ group

(HR, 4.16; $p<0.01)$, Ly (HR, $2.13 \mathrm{p}=0.01)$, V (HR, 2.99; $p<0.01$ ), and preCRP level (HR, 3.17; $p<0.01$ ) were identified as significant prognostic factors in the univariate analysis. Differentiation ( $\mathrm{HR}, 2.33 ; \mathrm{p}=0.03)$ and preCRP (HR, 3.08; $p<0.01)$ were identified as significant prognostic factors in the multivariate analysis.
The univariate and multivariate analyses of factors associated with OS for pathological stage I are summarized in Table 7 (Supplemental 2). Sex (HR, 6.53; $p<0.01$ ), smoking history (HR, 11.92; $\mathrm{p}<0.01)$, histology (HR, 2.67; $p=$ $0.01)$, differentiation (HR, 3.66; $\mathrm{p}<0.01), \mathrm{V}(\mathrm{HR}, 3.97$; $\mathrm{p}<0.01)$, and preCRP level $(\mathrm{HR}, 3.07 ; \mathrm{p}<0.01)$ were 
Table 4 Cox proportional hazard analyses for factors affecting relapse free survival

\begin{tabular}{|c|c|c|c|c|c|}
\hline \multirow{2}{*}{ Variables } & & \multicolumn{2}{|c|}{ Univariate analysis } & \multicolumn{2}{|c|}{ Multivariate analysis } \\
\hline & & $\mathrm{HR}(95 \% \mathrm{Cl})$ & $\overline{p \text {-value }}$ & $\mathrm{HR}(95 \% \mathrm{Cl})$ & $p$-value \\
\hline \multirow[t]{2}{*}{ Gender } & female & 1 & & & \\
\hline & male & $1.92(1.27-2.99)$ & $<0.01$ & & \\
\hline \multirow[t]{2}{*}{ Age } & $<70 y$ & 1 & & & \\
\hline & $\geq 70 y$ & $1.11(0.75-1.63)$ & 0.57 & & \\
\hline \multirow[t]{2}{*}{ Charlson comorbidity index } & $0-2$ & 1 & & & \\
\hline & $3-4$ & $1.29(0.41-7.85)$ & 0.70 & & \\
\hline \multirow[t]{2}{*}{ Smoking status } & never & 1 & & & \\
\hline & Former / current & $2.10(1.38-3.28)$ & $<0.01$ & & \\
\hline \multirow[t]{2}{*}{ CEA } & $\leq 5 \mathrm{ng} / \mathrm{ml}$ & 1 & & 1 & \\
\hline & $>5 \mathrm{ng} / \mathrm{ml}$ & $1.98(1.36-2.89)$ & $<0.01$ & $1.58(1.05-2.38)$ & 0.02 \\
\hline \multirow[t]{2}{*}{ Operative approach } & Thoracotomy & 1 & & & \\
\hline & VATS & $0.57(0.33-0.82)$ & $<0.01$ & & \\
\hline \multirow[t]{2}{*}{ Wound length } & $\leq 10 \mathrm{~cm}$ & 1 & & & \\
\hline & $>10 \mathrm{~cm}$ & 2.07 (1.37-3.08) & $<0.01$ & & \\
\hline \multirow[t]{2}{*}{ Operation time } & $\leq 248 \min$ & 1 & & & \\
\hline & $>248 \min$ & $1.62(1.09-2.44)$ & $<0.01$ & & \\
\hline \multirow[t]{2}{*}{ Operative procedure } & Seg / Lob & 1 & & & \\
\hline & Bilob / Pneumo & $1.99(1.01-3.55)$ & 0.04 & & \\
\hline \multirow[t]{2}{*}{ pStage } & । & 1 & & 1 & \\
\hline & $\|-\| A$ & $4.59(3.13-6.78)$ & $<0.01$ & $2.57(1.60-4.18)$ & $<0.01$ \\
\hline \multirow[t]{2}{*}{ Histology } & $\mathrm{Ad}$ & 1 & & & \\
\hline & Non-Ad & $1.32(0.86-1.97)$ & 0.19 & & \\
\hline \multirow[t]{2}{*}{ Differentiation } & G1 & 1 & & & \\
\hline & $\mathrm{G} 2-\mathrm{G} 4$ & $2.09(1.38-3.24)$ & $<0.01$ & & \\
\hline \multirow[t]{2}{*}{ Ly } & absent & 1 & & & \\
\hline & present & $4.38(2.25-9.01)$ & $<0.01$ & & \\
\hline \multirow[t]{2}{*}{ V } & absent & 1 & & 1 & \\
\hline & present & $3.26(2.16-5.05)$ & $<0.01$ & $1.95(1.15-3.38)$ & 0.01 \\
\hline \multirow[t]{2}{*}{ preCRP } & $\leq 0.14$ & 1 & & 1 & \\
\hline & $>0.14$ & $2.80(1.91-4.17)$ & $<0.01$ & $1.91(1.22-3.00)$ & $<0.01$ \\
\hline \multirow[t]{2}{*}{ postCRP } & $\leq 14.49$ & 1 & & & \\
\hline & $>14.49$ & $1.83(1.24-2.72)$ & $<0.01$ & & \\
\hline \multirow[t]{2}{*}{ Clavien-Dindo grade } & $0-1$ & 1 & & & \\
\hline & $\|-\||| b$ & $1.36(0.86-2.09)$ & 0.17 & & \\
\hline
\end{tabular}

CEA carcinoembryonic antigen, VATS video-assisted thoracic surgery, Seg segmentectomy, Lob lobectomy, Bilob bilobectomy, Pneumo pneumonectomy, pStage pathological stage,

Ly lymphatic invasion, $V$ vascular invasion, preCRP preoperative $C$-reactive protein, postCRP postoperative C-reactive protein

identified as significant prognostic factors in the univariate analysis. Smoking status (HR, 9.05; $\mathrm{p}<0.01), \mathrm{V}$ (HR, 3.20; $\mathrm{p}=0.01)$ and preCRP (HR, 2.21; $p=0.04)$ were identified as significant prognostic factors in the multivariate analysis.

\section{Discussion}

We showed that VATS was associated with a significantly shorter wound length and operation time, and lower postCRP level in comparison to thoracotomy in patients who underwent surgery for NSCLC. VATS has been reported to be associated with less pain, a shorter hospital stay and a reduced cytokine response in comparison to thoracotomy [4-10]. CRP and interleukin (IL)- 6 have often been analyzed as parameters of operative invasiveness, and in patients who undergo VATS, these values are significantly 
Table 5 Cox proportional hazard analyses for factors affecting overall survival

\begin{tabular}{|c|c|c|c|c|c|}
\hline \multirow{2}{*}{ Variables } & & \multicolumn{2}{|c|}{ Univariate analysis } & \multicolumn{2}{|c|}{ Multivariate analysis } \\
\hline & & $\mathrm{HR}(95 \% \mathrm{Cl})$ & $p$-value & $\mathrm{HR}(95 \% \mathrm{Cl})$ & $p$-value \\
\hline \multirow[t]{2}{*}{ Gender } & female & 1 & & & \\
\hline & male & $3.32(1.89-6.31)$ & $<0.01$ & & \\
\hline \multirow[t]{2}{*}{ Age } & $<70 y$ & 1 & & & \\
\hline & $\geq 70 y$ & $1.08(0.67-1.70)$ & 0.74 & & \\
\hline \multirow[t]{2}{*}{ Charlson comorbidity index } & $0-2$ & 1 & & & \\
\hline & $3-4$ & $1.37(0.22-4.38)$ & 0.67 & & \\
\hline \multirow[t]{2}{*}{ Smoking status } & never & 1 & & 1 & \\
\hline & Former /current & $4.12(2.31-8.03)$ & $<0.01$ & $2.36(1.07-5.56)$ & 0.03 \\
\hline \multirow[t]{2}{*}{ CEA } & $\leq 5 \mathrm{ng} / \mathrm{ml}$ & 1 & & & \\
\hline & $>5 \mathrm{ng} / \mathrm{ml}$ & $1.88(1.20-2.95)$ & $<0.01$ & & \\
\hline \multirow[t]{2}{*}{ Operative approach } & Thoracotomy & 1 & & & \\
\hline & VATS & $0.45(0.28-0.75)$ & $<0.01$ & & \\
\hline \multirow[t]{2}{*}{ Wound length } & $\leq 10 \mathrm{~cm}$ & 1 & & & \\
\hline & $>10 \mathrm{~cm}$ & $2.41(1.51-3.79)$ & $<0.01$ & & \\
\hline \multirow[t]{2}{*}{ Operation time } & $\leq 248 \min$ & 1 & & & \\
\hline & $>248 \min$ & $1.84(1.09-3.23)$ & 0.02 & & \\
\hline \multirow[t]{2}{*}{ Operative procedure } & Seg / Lob & 1 & & & \\
\hline & Bilob / Pneumo & $2.98(1.48-5.41)$ & $<0.01$ & & \\
\hline \multirow[t]{2}{*}{ pStage } & I & 1 & & 1 & \\
\hline & $\|-\| A$ & $4.83(3.05-7.82)$ & $<0.01$ & $3.26(1.77-6.08)$ & $<0.01$ \\
\hline \multirow[t]{2}{*}{ Histology } & $\mathrm{Ad}$ & 1 & & & \\
\hline & Non-Ad & $1.60(0.98-2.55)$ & 0.05 & & \\
\hline \multirow[t]{2}{*}{ Differentiation } & G1 & 1 & & & \\
\hline & $\mathrm{G} 2-\mathrm{G} 4$ & $1.92(1.19-3.17)$ & $<0.01$ & & \\
\hline \multirow[t]{2}{*}{ Ly } & absent & 1 & & & \\
\hline & present & $1.95(1.24-3.11)$ & $<0.01$ & & \\
\hline \multirow[t]{2}{*}{ V } & absent & 1 & & 1 & \\
\hline & present & $3.36(2.06-5.69)$ & $<0.01$ & $2.80(1.49-5.38)$ & $<0.01$ \\
\hline \multirow[t]{2}{*}{ preCRP } & $\leq 0.14$ & 1 & & & \\
\hline & $>0.14$ & $2.85(1.80-4.61)$ & $<0.01$ & & \\
\hline \multirow[t]{2}{*}{ postCRP } & $\leq 14.49$ & 1 & & & \\
\hline & $>14.49$ & $2.20(1.35-3.69)$ & $<0.01$ & & \\
\hline \multirow[t]{2}{*}{ Clavien-Dindo grade } & $0-1$ & 1 & & & \\
\hline & $\|-\| I \| b$ & $1.45(0.83-2.43)$ & 0.17 & & \\
\hline
\end{tabular}

CEA carcinoembryonic antigen, VATS video-assisted thoracic surgery, Seg segmentectomy, Lob lobectomy, Bilob bilobectomy, Pneumo pneumonectomy, pStage pathological stage,

Ly lymphatic invasion, $V$ vascular invasion, preCRP preoperative $C$-reactive protein, postCRP postoperative $C$-reactive protein

lower in comparison to those who undergo thoracotomy [8-10]. In the present study, the operation time and wound length were positively correlated with the postCRP level; thus, it was suggested that the operation time and wound length are associated with operative invasiveness and that VATS is less invasive approach.
The relationship between operative invasiveness, including the postoperative inflammatory response, and the prognosis of NSCLC patients who undergo surgery has not been clear. VATS has been reported to result in reduced postoperative CRP and IL-6 levels in comparison to thoracotomy [8-10, 13-16]. IL- 6 has been reported to promote cell proliferation 
[17-20], affect insulin growth factor (IGF), and result in insulin growth factor binding protein (IGFBP) 3 inhibition, thereby contributing to an environment favoring tumor proliferation in patients with NSCLC $[21,22]$. Although some reports have demonstrated a prognostic advantage of VATS in comparison to thoracotomy, it was considered that the prognostic advantage was influenced by a patient bias [23, 24]. The present study also demonstrated that the DFS and OS of the VATS group were better than those in the thoracotomy group; however, a multivariate analysis of DFS and OS confirmed the nonsuperiority of VATS. Because other reports demonstrated that long-term survival after VATS is not inferior in comparison to thoracotomy, it might be revealed that a less invasive operative approach itself is not a prognostic factor [24-27].

The present study identified the preCRP level as a significant prognostic factor for recurrence in patients who received surgery. Previous studies reported that the CRP level is an important prognostic factor in NSCLC patients [28-30]. Several mechanisms for the elevation of the CRP level in cancer patients have been proposed. First, tumor growth might cause tissue inflammation and CRP elevation [31, 32]. Second, CRP might be an indicator of the immune response to tumor antigens [33-35]. Third, there is evidence that cancer cells increase the production of inflammatory proteins such as CRP. Based on these mechanisms, patients with high preCRP levels might already have a cytological tumor spread that cannot be detected by either imaging studies or pathologic examinations. Furthermore, circulating cancer cells might be responsible for early recurrence in patients with high preCRP levels. A previous study demonstrated that CRP is positively correlated with the pathological tumor size and pathological stage in NSCLC patients [28]; thus, the preCRP level might be a prognostic indicator for NSCLC patients who have undergone surgery.

The present study was associated with several limitations. First, the study was retrospective in nature, and potentially involved unobserved cofounding and selection biases. Second, the present study was performed at a single institution, and the study population was relatively small.

\section{Conclusions}

Our findings suggested that operation time and wound length reflect operative invasiveness and that VATS is a less invasive approach for NSCLC patients who have undergone surgery. Although VATS itself might be not a prognostic factor, the preCRP level might be a prognostic factor in NSCLC patients who have undergone surgery.

\section{Supplementary information}

Supplementary information accompanies this paper at https://doi.org/10. 1186/s12890-020-01264-X.

\section{Additional file 1.}

Additional file 2.

\begin{abstract}
Abbreviations
NSCLC: Non-small cell lung cancer; postCRP: postoperative C-reactive protein VATS: Video-assisted thoracic surgery; CC: Correlation coefficient; HR: Hazard ratio; pStage: pathological stage; preCRP: preoperative CRP level; APPS: Acute-phase proteins; CEA: Carcinoembryonic antigen; CVATS: Complete VATS; H-VATS: Hybrid VATS; Ly: Lymphatic invasion; V: Vascular invasion; RFS: Relapse-free survival; OS: Overall survival;

IL: Interleukin; IGF: Insulin growth factor; IGFBP: Insulin growth factor binding protein
\end{abstract}

Acknowledgements

Not applicable.

\section{Authors' contributions}

All authors have read and approved the manuscript. N. M. performed the research, collected and analyzed the data and wrote the paper. S. I., Y. I, and K. U. contributed to sample collection. H. U. contributed to supervision of this study and revision of the manuscript.

\section{Funding}

This study has not been funded.

\section{Availability of data and materials}

The data sets supporting the conclusions of the present study are included in this published article.

\section{Ethics approval and consent to participate}

The Institutional Review Boards of Kanazawa Medical University approved the protocol of this study (I392), and written informed consent was obtained from all of the patients.

Consent for publication

Not applicable.

\section{Competing interests}

The authors declare that they have no competing interests.

Received: 27 May 2020 Accepted: 17 August 2020

Published online: 15 October 2020

References

1. Mckenna RJ Jr, Houck W, Fuller CB. Video-assisted thoracic surgery lobectomy: experience with 1,100 cases. Ann Thorac Surg. 2006;81:421-6.

2. Flores RM, Park BJ, Dycoco J, Aronova A, Hirth Y, Rizk NP, et al. Lobectomy by video-assisted surgery (VATS) versus thoracotomy for lung cancer. J Thorac Cardiovasc Surg. 2009;138:11-8.

3. Whitson BA, Groth SS, Duval SJ, Swanson SJ, Maddaus MA. Surgery for earlystage non-small cell lung cancer: a systematic review of the video-assisted thoracoscopic surgery versus thoracotomy approaches to lobectomy. Ann Thorac Surg. 2008;86:2008-18.

4. Sakuraba M, Miyamoto H, Oh S, Shiomi K, Sonobe S, Takahashi N, et al. Video-assisted thoracoscopic lobectomy vs. conventional lobectomy via open thoracotomy in patients with clinical stage IA non-small cell lung carcinoma. Interact Cardiovasc Thorac Surg. 2007:6:614-7.

5. Rizk NP, Ghanie A, Hsu M, Bains MS, Downey RJ, Sarkaria IS, et al. A prospective trial comparing pain and quality of life measures after anatomic lung resection using thoracoscopy or thoracotomy. Ann Thorac Surg. 2014; 98:1160-6.

6. Shao C, Zheng C, Yan W, Shen Y, Zhang Z. Evaluation of efficacy and safety of minimally invasive segmentectomy in the treatment of lung cancer. Oncol Lett. 2018;15:9516-22. 
7. Yim APC, Wan S, Lee TW, Arifi AA. VATS lobectomy reduces cytokine responses compared with conventional surgery. Ann Thorac Surg. 2000; 70(1):243-7.

8. Liu HF, Ren QM, Wang ZB, Li X, Jiang S, Zhang JT, et al. Comparison of acute phase protein and hemodynamic variables in dogs undergoing video-assisted thoracoscopic vs. open pneumonectomy. Exp Ther Med. 2017;13:2391-8.

9. Liu HF, Gao L, Liu T, Jiang Y, Wang HB. Comparison of acute phase reaction and postoperative stress in pigs undergoing video-assisted thoracoscopic versus thoracotomy pneumonectomy. Acta Vet Scand. 2016;58:75.

10. Charlson ME, Pompei P, Ales KL, MacKenzie CR. A new method of classifying prognostic comorbidity in longitudinal studies: development and validation. J Choric Dis. 1987:40:373-83.

11. Katayama H, Kurokawa Y, Nakamura K, Ito H, Kanemitsu Y, Masuda N, et al. Extended Clavien-Dindo classification of surgical complications: Japan clinical oncology group postoperative complications criteria. Surg Today. 2016:46:668-85.

12. Craig SR, Leaver HA, Yap PL, Pugh GC, Walker WS. Acute phase responses following minimal access and conventional thoracic surgery. Eur J Cardiothorac Surg. 2001;20:455-63.

13. Nagahiro I, Ando A, Aoe M, Sano Y, Date H, Shimizu N. Pulmonary function, postoperative pain, and serum cytokine level after lobectomy: a comparison of VATS and conventional procedure. Ann Thorac Surg. 2001;72:362-5.

14. Ito Y, Oda M, Tsunezuka Y, Matsumoto I, Ishikawa N, Kamakami K, et al. Reduced perioperative immune response in video-assisted versus open surgery in rat model. Surg Today. 2009;39:682-8.

15. Poncet N, Guillaume J, Mouchiroud G. Epidermal growth factor receptor transactivation is implicated in IL-6-induced proliferation and ERK1/2 activation in non-transformed prostate epithelial cells. Cell Singal. 2011;23: 572-28.

16. Ara T, Declerck YA. Interleukin-6 in bone metastasis and cancer progression. Eur J Cancer. 2010:46:1223-31.

17. Hov H, Tian E, Holien T, Holt RU, Vátsveen TK, Fagerli UM, et al. C-met signaling promotes IL-6-induced myeloma cell proliferation. Eur J Haematol. 2009;82:277-87.

18. Walter M, Liang S, Ghosh S, Hornsby PJ, Li R. Interleukin 6 secreted from adipose stromal cells promotes migration and invasion of breast cancer cells. Oncogene. 2009;28:2745-55.

19. $\mathrm{Ng}$ CSH, Whelan RL, Lacy AM, Yim APC. Is minimal access surgery for cancer associated with immunologic benefits? World J Surg. 2005;29:975-81.

20. Chang KT, Tsai CM, Chiou YC, Chiu CH, Jeng KS, Huang CY. IL-6 induces neuroendocrine dedifferentiation and cell proliferation in nonsmall cell lung cancer cells. Ann J Physiol Lung Cell Mol Physiol. 2005; 289:L446-53.

21. Berry MF, D'Amico TA, Onaitis MW, Kelsey CR. Thoracoscopic approach to lobectomy for lung cancer does not compromise oncologic efficacy. Ann Thorac Surg. 2014;98:197-202.

22. Sawada S, Komori E, Yamashita M, Nakata M, Nishimura R, Teramoto N, et al. Comparison in prognosis after VATS lobectomy and open lobectomy for stage I lung cancer. Surg Endosc. 2007;21:1607-11.

23. Higuchi M, Yaginuma $H$, Yonechi A, Kanno R, Ohishi A, Suzuki H, et al. Longterm outcomes after video-assisted thoracic surgery (VATS) lobectomy versus lobectomy via open thoracotomy for clinical stage IA non-small cell lung cancer. J Card Surg. 2014;9:88.

24. Boffa DJ, Kosinski AS, Furnary AP, Kim S, Onaitis MW, Tong BC, et al. Minimmally invasive lung cancer surgery performed by thoracic surgeons as effective as thoracotomy. J Clin Oncol. 2018;36:2378-85.

25. Lee PC, Nasar A, Port JL, Paul S, Stiles B, Chiu YL, et al. Long-term survival after lobectomy for non-small cell lung cancer by video-assisted thoracic surgery versus thoracotomy. Ann Thorac Surg. 2013;96:951-61.

26. Aref H, Refaat S. CRP evaluation in non-small cell lung cancer. Egypt J Chest Dis Tuberc. 2014;63:717-22

27. Hara M, Matsuzaki Y, Shimuzu T, Tomita M, Ayabe T, Enomoto $Y$, et al. Preoperative serum C-reactive protein level in non-small cell lung cancer. Anticancer Res. 2007;27:3001-4

28. Shrotriya S, Walsh D, Nowacki AS, Lorton C, Aktas A, Hullihen B, et al. Serum C-reactive protein in an important and powerful prognostic biomarker in most adult solid tumors. PLoS One. 2018;13:e0202555.

29. Basso D, Fabris C, Meani A, Del Favero G, Vianello D, Angonese C, et al. C reactive protein in pancreatic cancer and chronic pancreatitis. Ann Clin Res. 1988;20:414-6.
30. O'Hanlon DM, Lynch J, Cormican M, Given HF. The acute phase response in breast carcinoma. Anticancer Res. 2002;22:1289-93.

31. Alexandrakis MG, Passam FH, Moschandrea IA, Christophoridou AV, Pappa CA, Coulocheri SA, et al. Levels of serum cytokines and acute phase proteins in patients with essential and cancer-related thrombocytosis. Am J Clin Oncol. 2003;26:135-40.

32. Balkwill F, Mantovani A. Inflammation and cancer: back to Virchow? Lancet. 2001;357:539-45.

33. Blann AD, Byrne GJ, Baildam AD. Increased soluble intercellular adhesion molecule-1, breast cancer and the acute phase response. Blood Coagul Fibrinolysis. 2002;13:165-8.

34. Nozoe T, Korenaga D, Futatsugi M, Saeki H, Maehara Y, Sugimachi K. Immunohistochemical expression of C-reactive protein in squamous cell carcinoma of the esophagus - significance as a tumor marker. Cancer Lett. 2003:192:89-95.

35. Jabs WJ, Busse M, Krüger S, Jocham D, Steinhoff J, Doehn C. Expression of C-reactive protein by renal cell carcinomas and unaffected surrounding renal tissue. Kidney Int. 2005;68:2103-10.

\section{Publisher's Note}

Springer Nature remains neutral with regard to jurisdictional claims in published maps and institutional affiliations.
Ready to submit your research? Choose BMC and benefit from:

- fast, convenient online submission

- thorough peer review by experienced researchers in your field

- rapid publication on acceptance

- support for research data, including large and complex data types

- gold Open Access which fosters wider collaboration and increased citations

- maximum visibility for your research: over $100 \mathrm{M}$ website views per year

At $\mathrm{BMC}$, research is always in progress.

Learn more biomedcentral.com/submissions 